\title{
Lumpfish (Cyclopterus lumpus, Linnaeus) is susceptible to viral nervous necrosis: Result of an experimental infection with different genotypes of Betanodavirus
}

Toffan, Anna; De Salvador, Maria; Scholz, Felix; Pretto, Tobia; Buratin, Alessandra; Rodger, Hamish D; Toson, Marica; Cuenca, Argelia; Vendramin, Niccolò

Published in:

Journal of Fish Diseases

Link to article, DOI:

$10.1111 / \mathrm{jfd} .13088$

Publication date:

2019

Document Version

Peer reviewed version

Link back to DTU Orbit

Citation (APA):

Toffan, A., De Salvador, M., Scholz, F., Pretto, T., Buratin, A., Rodger, H. D., Toson, M., Cuenca, A., \& Vendramin, N. (2019). Lumpfish (Cyclopterus lumpus, Linnaeus) is susceptible to viral nervous necrosis: Result of an experimental infection with different genotypes of Betanodavirus. Journal of Fish Diseases, 42(12), 16671676. https://doi.org/10.1111/jfd.13088

\section{General rights}

Copyright and moral rights for the publications made accessible in the public portal are retained by the authors and/or other copyright owners and it is a condition of accessing publications that users recognise and abide by the legal requirements associated with these rights.

- Users may download and print one copy of any publication from the public portal for the purpose of private study or research.

- You may not further distribute the material or use it for any profit-making activity or commercial gain

- You may freely distribute the URL identifying the publication in the public portal 
See discussions, stats, and author profiles for this publication at: https://www.researchgate.net/publication/336554688

\section{Lumpfish (Cyclopterus lumpus, Linnaeus) is susceptible to viral nervous necrosis: Result of an experimental infection with different genotypes of Betanodavirus}

Article in Journal of Fish Diseases · October 2019

DOI: $10.1111 /$ jfd. 13088

9 authors, including:

Anna Toffan

Istituto Zooprofilattico Sperimentale delle Venezie 159 PUBLICATIONS 1,409 CITATIONS

SEE PROFILE

\section{Tobia Pretto}

Istituto Zooprofilattico Sperimentale delle Venezie

32 PUBLICATIONS 221 CITATIONS

SEE PROFILE

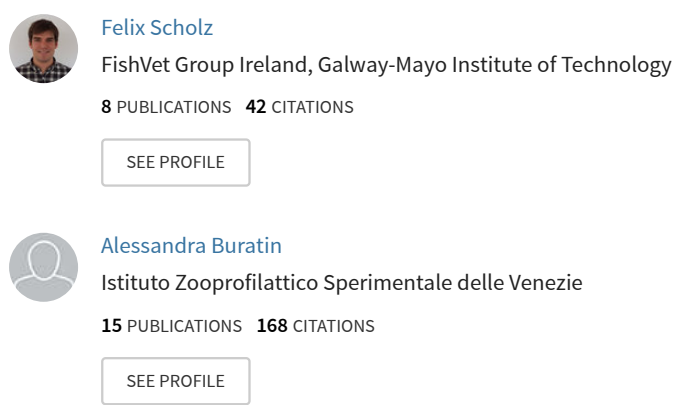

Some of the authors of this publication are also working on these related projects:

TARGETFISH View project

Koi Herpesvirus: implementazione di un programma di sorveglianza a seguito di un evento di mortalità View project 


\title{
Lumpfish (Cyclopterus lumpus, Linnaeus) is susceptible to viral nervous necrosis: Result of an experimental infection with different genotypes of Betanodavirus
}

\author{
Anna Toffan $^{1}$ (D) | Maria De Salvador ${ }^{2}$ | Felix Scholz ${ }^{3}$ | Tobia Pretto $^{1}$ | \\ Alessandra Buratin $^{1}$ | Hamish D. Rodger ${ }^{3}$ | Marica Toson ${ }^{1}$ | Argelia Cuenca ${ }^{4}$ | \\ Niccolò Vendramin ${ }^{4}$
}

${ }^{1}$ Istituto Zooprofilattico Sperimentale delle Venezie (IZSVe), Legnaro, Padua, Italy

${ }^{2}$ Università degli studi di Udine, Udine, Italy

${ }^{3}$ FishVet Group Ireland, Oranmore, Galway, Ireland

${ }^{4}$ National Institute of Aquatic

Resources, EURL for fish and crustacean diseases, Technical University of Denmark, Lyngby, Denmark

\section{Correspondence}

Anna Toffan, Istituto Zooprofilattico Sperimentale delle Venezie (IZSVe), National Reference centre for fish diseases, OIE Reference Laboratory for Viral EncephaloRetinopathy, Viale dell'Università 10, Legnaro, Padua, Italy.

Email: atoffan@izsvenezie.it

Funding information

Horizon 2020 -SFS-10a-2014 Research and Innovation Action, Grant/Award Number: ParaFishControl GA No 634429; Horizon 2020 INFRAIA -1-2014-/2015, Grant/Award Number: AQUAEXCEL2020 GA No 652831

\begin{abstract}
In recent years, the use of cleaner fish for biological control of sea lice has increased considerably. Along with this, a number of infectious diseases have emerged. The aim of this study was to investigate the susceptibility of lumpfish (Cyclopterus lumpus) to Betanodavirus since it was detected in asymptomatic wild wrasses in Norway and Sweden. Three betanodaviruses were used to challenge lumpfish: one RGNNV genotype and two BFNNV genotypes. Fish were injected and monitored for 4 weeks. Brain samples from clinically affected specimens, from weekly randomly selected fish and survivors were subjected to molecular testing, viral isolation, histopathology and immunohistochemistry. Reduced survival was observed but was attributed to tail-biting behaviour, since no nervous signs were observed throughout the study. Betanodavirus RNA was detected in all samples, additionally suggesting an active replication of the virus in the brain. Viral isolation confirmed molecular biology results and revealed a high viral titre in BFNNV-infected groups associated with typical lesions in brains and eyes of survivor fish. We concluded that lumpfish are susceptible to Betanodavirus, as proven by the high viral titre and brain lesions detected, but further studies are necessary to understand if Betanodavirus can cause clinical disease in this species.
\end{abstract}

\section{KEYWORDS}

Betanodavirus, cleaner fish, lumpfish, nervous necrosis virus, viral encephalopathy and retinopathy

\section{1 | INTRODUCTION}

Viral encephalopathy and retinopathy (VER), otherwise known as viral nervous necrosis (VNN), is a major threat for aquatic animals. The causative agent of VNN is the nervous necrosis virus (NNV), a small (25-30 nm diameter), icosahedral, non-enveloped viral particle, with a bi-segmented genome made of two single-stranded positive-sense RNA molecules, classified as a member of the Nodaviridae family, genus Betanodavirus (Doan, Vandeputte, Chatain, Morin, \& Allal, 2017).

A large number of finfish species have been reported to be affected, especially at larval and juvenile stages in which high mortalities were recorded (Doan et al., 2017; Munday, Kwang, \& Moody, 2002; OIE, 2017; Shetty, Maiti, Santhosh, Venugopal, \& Karunasagar, 2012).

This infectious agent, detected in the early nineties, rapidly spread worldwide. The disease has recently been included among 
the most significant viral pathogens of finfish, given the expanding host range and the lack of prophylactic measures (Rigos \& Katharios, 2010; Shetty et al., 2012; Walker \& Winton, 2010). VNN is characterized by typical behavioural abnormalities (erratic swimming patterns such as spiralling or whirling, lying on the tank bottom, rapid swimming, darker coloration) associated with an impairment of the nervous system (Breuil, Bonami, Pepin, \& Pichot, 1991; Chi et al., 1997; Hata et al., 2010; Yoshikoshi \& Inoue, 1990). In larvae/ juveniles, the onset of the disease can be hyper-acute, the only apparent clinical sign being a sharp increase in mortality. In older animals, the cumulative mortality can be lower, but it impairs the performance of the affected batch by reducing fish growth and enhancing the unevenness in weight/size (Vendramin et al., 2014). This represents an indirect but significant economic loss, which is often underestimated. The most common microscopical findings consist of vacuolation and necrosis of nervous cells of the spinal cord, brain and/or retina, particularly in larval and juvenile stages (Doan et al., 2017). Histological analyses of the central nervous system (CNS) reveal the presence of encephalopathy characterized by multiple intracytoplasmatic vacuolation (Grove, Johansen, Dannevig, Reitan, \& Ranheim, 2003; Lopez-Jimena et al., 2011; Maltese \& Bovo, 2007; Mladineo, 2003; Munday et al., 2002).

The biological control of sea lice (Lepeophtheirus salmonis) on Atlantic salmon (Salmo salar) through the use of cleaner fish has recently become a promising alternative due to the increased occurrence of resistant sea lice, the reduced public acceptance of chemotherapeutic use in food production, and the urgent need for an effective and sustainable method of sea louse control in Atlantic salmon aquaculture (Treasurer, 2002). In recent years, the use of lumpfish (Cyclopterus lumpus, L.) as cleaner fish has increased considerably in Norway, Scotland and Ireland (Alarcón, Thoen, et al., 2016; Bolton-Warberg, 2018). Lumpfish, also known as lumpsuckers, grow faster and are easier to breed in captivity than wrasse species, as well as being more suitable for louse control under cold-water conditions, as in Norway, as they remain active at low water temperatures (Imsland et al., 2014). Demand for lumpfish has therefore increased exponentially since 2012 (Powell et al., 2018); however, nearly all lumpfish used in salmon farming are still derived from wild broodstock (Jonassen, Remen, Levka, Steinarsson, \& Arnason, 2018).

New diseases and infectious agents inevitably emerge when new species are introduced to aquaculture, and the lumpfish appears to pose no exception to this rule. A range of different pathogens has been detected in wild and farmed lumpfish, including viruses, bacteria, parasites and fungi (Alarcón, Gulla, et al., 2016; Alarcón, Thoen, et al., 2016; Guðmundsdóttir et al., 2019; Hjeltnes, 2014; Johansen, 2013; Marcos-López, Donald, Stagg, \& McCarthy, 2013; Poppe et al., 2012; Scholz et al., 2017; Scholz, Ruane, Marcos-Lopez, et al., 2018; Skoge, Brattespe, Økland, Plarre, \& Nylund, 2018; Stagg et al., 2017; Treasurer \& Birkbeck, 2018). Finally, the possible role of cleaner fish as subclinical carrier for viral disease has emerged (Rimstad Basic, Gulla, \& Hjeltnes \& Mortensen, 2017). They therefore have to be considered potential reservoirs, posing a possible biosecurity risk to salmon and other farmed fish, especially if reused or moved between sites or pens (Scholz, Ruane, Morrissey, et al., 2018).

Based on the recent scientific demonstration of natural and experimental cases of viral haemorrhagic septicaemia virus (VHSV) in lumpfish and wrasses, these species were included among susceptible species in the Commission Implementing Regulation 1882/2018 of the European Directive 2016/429/EC and should be accompanied by an animal health certificate when moved.

Korsnes et al. (2017) have recently reported the detection of NNV RNA with $6.7 \%$ overall prevalence in wild wrasse caught in southern Norway and Sweden. That study showed that NNV was present in different species of wild wrasses along the coastline of Sweden and Norway. Sequence analysis of the RNA2 segment of NNVs detected revealed high genetic variability; the viruses were grouped into two clusters within the cold-water BFNNV and warm-water RGNNV genogroups. Despite no clinical signs being detected in infected wrasse, the authors suggested a carrier state of NNV for these fish and concluded that the use of wild-caught wrasse might represent a risk of introducing NNV into aquaculture.

Lumpfish and wrasses share the same environment for part of the year in some geographic areas and are frequently cohabited when stoked as cleaner fish in salmon pens, but at present, there are no data about lumpfish susceptibility to NNV. Notably, the number of lumpfish deployed in Norway has reached 40 million in 2018 and has exceeded the use of wrasse (B. Hjeltnes, Personal Communication). The aim of the present study was to determine the susceptibility of lumpfish to three genetically different betanodaviruses as part of the risk assessment for using lumpfish in aquaculture.

\section{MATERIALS AND METHODS}

\section{1 | Fish}

The experiments were carried out at DTU-Aqua (Kgs. Lyngby, Denmark) in accordance with the recommendation in the current European animal welfare regulations under licence 2013-15-2934-00976. Juvenile lumpfish (Cyclopterus lumpus, L.), mean weight $0.17 \mathrm{~g}$, were imported from a commercial hatchery in Iceland; the parental stocks were tested by cell culture, bacteriology and real-time RT-PCR (rRT-PCR) for the absence of VHSV and NNV. All fish were acclimatized in a quarantine system for 2 weeks before use. Experimental fish were further screened with bacteriological examinations (kidney material streaked onto marine agar and blood agar, incubated for 2 weeks at $15^{\circ} \mathrm{C}$ ), with virus isolation on cell culture Epithelioma papulosum cyprini (EPC) (Fijan et al., 1983) and bluegill fry-2 (BF-2) cell lines (Wolf \& Quimby, 1962), and with parasitological examination (skin and gill scrapes observed by light microscopy). All results were negative.

\section{2 | Viruses}

A summary of the characteristics of the viral strains used in this study is reported in Table 1. In detail, strain 459.18/I12 was isolated 
during a surveillance activity for monitoring the NNV presence in the Ionian Sea performed by IZSVe from 2011 to 2014. Surveillance was performed by rRT-PCR and virus isolation on SSN-1 cells on more than 600 wild fish caught during scuba-diving excursions and with experimental fishnets close to sea cages of a local sea bass/ sea bream farm. Among several fish species found VNN positive, one isolate coming from brain samples of an asymptomatic peacock wrasse (Symphodus tinca), called 459.18/I12, was selected for this study. The virus isolate was characterized as belonging to the RGNNV species (Toffan \& Patarnello, 2013).

Strains Ah95NorA and SK-07 1324 were isolated from diseased Atlantic halibut (Hippoglossus hippoglossus) and Atlantic cod (Gadus morhua), respectively (Grotmol, Nerland, Biering, Totland, \& Nishizawa, 2000; Grotmol, Totland, Thorud, \& Hjeltnes, 1997; Patel et al., 2007; Totland, Grotmol, Morita, Nishioka, \& Nakai, 1999). These viruses were characterized as belonging to the BFNNV genotype. Both viruses were kindly provided by Dr. Hilde Sindre from the Norwegian Veterinary Institute.

\section{3 | Virus preparation}

For challenge trials, the isolates were grown on SSN-1 cells (Frerichs, Tweedie, Starkey, \& Richards, 2000) at $20^{\circ} \mathrm{C}$ for BFNNV strains and $25^{\circ} \mathrm{C}$ for RGNNV strain and the cell culture supernatant was sterile-filtered $(0.22 \mu \mathrm{m})$. The collected virus was subjected to titration by endpoint dilutions assays. Titres were calculated according to the Spearman-Karber formula (Finney, 1978) and expressed as TCID ${ }_{50} /$ $\mathrm{ml}$.

Infected cell culture supernatants were diluted with sterile EMEM (Eagle's minimum essential medium; Sigma) to obtain a final concentration of $10^{5} \mathrm{TCID}_{50} / \mathrm{ml}$ for each viral strain.

\subsection{Challenge protocol and sampling}

Lumpfish were challenged after being anaesthetized with benzocaine $(80 \mathrm{mg} / \mathrm{L}$; Sigma). The infection was performed with an intramuscular injection $(0.1 \mathrm{ml} / \mathrm{fish})$ of infected culture supernatant titrating $10^{5} \mathrm{TCID}_{50} / \mathrm{ml}$. Fish used for negative control were anaesthetized like the other fish and were injected with $0.1 \mathrm{ml}$ of sterile E-MEM (Eagle's minimum essential medium).

Fish were divided into three different challenge groups, each one infected with a different virus, and a negative control group.

Each challenge group was divided in triplicate tanks, each tank containing 30 lumpfish. Negative control groups were tested in duplicate, each tank containing 30 fish. A total of 270 juvenile lumpfish were employed for this study. Fish were held in 8-L tanks on a flow-through system. Municipal dechlorinated water mixed with artificial marine salt (Koral Salt; Aquaconstruct, Copenhagen) to a final concentration of 20 ppt for lumpfish was used. Temperature was maintained at $12^{\circ} \mathrm{C}$. Fish were fed commercial pellets and tanks were cleaned twice daily for the first weeks. Every tank was equipped with independent aeration and biological filtration systems. Fish were provided with artificial algae as environmental 
enrichments. Fish were monitored for abnormal behaviour and signs of clinical disease. Inspections were performed at least twice daily for 28 days post-challenge concurrently with the food administration and other routine controls. The number of clinically affected fish was recorded daily, and moribund/diseased fish were collected, killed and processed as described in the virological examination paragraph. Surviving fish were killed with an overdose of benzocaine $(800 \mathrm{mg} / \mathrm{L})$ and counted. All survivors were collected from every tank.

Samples were collected as follows: two apparently healthy fish were taken from each tank every week for four weeks and were killed with an overdose of benzocaine $(800 \mathrm{mg} / \mathrm{L})$. One entire fish was frozen at $-80^{\circ} \mathrm{C}$ and stored in Eagle's MEM, while the other one was fixed in buffered formalin for histological examination. Fish showing signs of disease (melanosis, fin rot, apathy) were killed with an overdose of benzocaine $(800 \mathrm{mg} / \mathrm{L})$, and entire fish were singularly frozen at $-80^{\circ} \mathrm{C}$ and stored in E-MEM or fixed in buffered formalin for histological examination. At the end of the study, all surviving fish were killed with an overdose of benzocaine $(800 \mathrm{mg} / \mathrm{L})$ and counted. All the samples collected were sent to Istituto Zooprofilattico Sperimentale delle Venezie (Legnaro, PD, Italy) for analysis.

\section{$2.5 \mid$ rRT-PCR}

All frozen samples were first prepared for rRT-PCR analysis, starting with negative control groups and then proceeding with the challenged groups. All fish were singularly processed.

From each individual specimen, the head (including brain and eyes) was dissected and homogenized with sterile quartz sand in sterile 2-ml Eppendorfs. Each sample was weighed, and sterile EMEM was added at a ratio of 1:3. Samples were then centrifuged at $20,000 \mathrm{~g}$ for $2 \mathrm{~min}$.

After centrifugation, 250 microlitres of supernatant was added to 300 microlitres of ATL lysis buffer (Qiagen) for RNA/DNA extraction with QIAsymphony ${ }^{\circledR}$ DSP Virus/Pathogen Midi Kit, used in combination with QIAsymphony SP, according to the manufacturer's instructions (Qiagen). The remaining samples were immediately stored at $-80^{\circ} \mathrm{C}$ for cell culture isolation. After extraction, pure nucleic acids were stored overnight at $2-8^{\circ} \mathrm{C}$.

The rRT-PCR protocol used for testing samples was developed by Baud et al. (2015) (Baud et al., 2015) and targets the RNA1 of all known Betanodavirus species. According to internal validation, samples with cycle threshold $(\mathrm{C} t)<34.00$ were considered positive, samples with $\mathrm{Ct}$ ranging from 34.00 and 36.00 were considered doubtful, and samples with $\mathrm{Ct}>36.00$ or showing no amplification were considered negative.

\section{6 | Viral isolation and titration}

As previously written, two samples per virus per tank per week were randomly chosen and submitted to viral isolation in cell culture. Viral isolation was then performed on 8 samples per viral strain, for a total of 24 samples. The same homogenized head samples used for rRT-PCR (prepared as described before) were frozen for possible cell culture pending PCR results. Then, from rRT-PCR-positive samples, the chosen samples of brain and eye homogenates were retrieved from $-80^{\circ} \mathrm{C}$ and centrifuged at $20,000 \mathrm{~g}$ for $2 \mathrm{~min}$. Then, 180 microlitres of supernatant added with 20 microlitres (10\%) of mixed antibiotic/antimycotic solution containing $10,000 \mathrm{IU} / \mathrm{ml}$ penicillin $\mathrm{G}, 10 \mathrm{mg} / \mathrm{ml}$ streptomycin sulphate, $25 \mu \mathrm{g} / \mathrm{ml}$ amphotericin B (Sigma) and $0.4 \%$ of $50 \mathrm{mg} /$ $\mathrm{ml}$ kanamycin solution (Sigma) were left in incubation with antibiotics overnight at $+4^{\circ} \mathrm{C}$ and finally inoculated at two different concentrations (1:10-1:100) on 24-well plates seeded with SSN-1 cells. Plates were incubated for 10 days at $20^{\circ} \mathrm{C}$ for Ah95NorA and SK-071324 or at $25^{\circ} \mathrm{C}$ for $459.18 /$ I12. Daily observation for appearance of cytopathic effect (CPE) was performed. Negative samples were subjected to a second passage of 10 days on fresh cell monolayer at the same temperature conditions as before.

In order to quantify the amount of virus in surviving fish infected with different NNV strains, groups of positive samples with similar rRT-PCR cycle threshold value (Ct) were selected and titrated in cell culture by endpoint dilutions.

Samples were selected according to the following criteria: 4 samples with $\mathrm{Ct}<15.00$, 4 samples with $\mathrm{Ct}$ ranging from 15.00 to 25.00 and 4 samples with $\mathrm{Ct}>25.00$. Final titres were calculated according to the Spearman-Karber formula (Finney, 1978) and expressed as $\mathrm{TCID}_{50} / \mathrm{ml}$.

\section{7 | Histology}

Samples fixed in $4 \%$ buffered formalin were processed for histopathological and immunohistochemical examination (Mutinelli, Bozza, Basilicata, \& Bovo, 1998). Briefly, samples were dehydrated through a graded ethanol-xylene series and embedded in paraffin. Sections of $3 \mu \mathrm{m}$ were first deparaffinized, rehydrated and then either stained with haematoxylin-eosin (H\&E) for histopathological examination or subjected to IHC as described below.

The immunohistochemical analysis was performed automatically from dewaxing to counterstaining using the BenchMark Ultra instrument (Roche) on tissue sections collected on poly-L-lysine-coated slide (HistoBond ${ }^{\circledR}+$; Marienfeld Superior). Between each reagent application, the slides were washed with Tris-buffered saline with Tween-20 (TBST).

Antigen retrieval was obtained through incubation (at $36^{\circ} \mathrm{C}$ for $32 \mathrm{~min}$ ) in Protease 2 enzyme (Roche), while non-specific antibody sites were blocked with DISCOVERY Goat Ig Block solution (Roche), consisting of casein and goat globulins in PBS, incubated at $36^{\circ} \mathrm{C}$ for $28 \mathrm{~min}$.

The IHC reaction was performed with a rabbit polyclonal serum against Betanodavirus RGNNV genotype produced in-house (PAb 283) (Panzarin et al., 2016), at the dilution of 1:5,000 for one hour at room temperature. Samples were incubated with the ultraView Red staining kit (Roche) based on a secondary antibody conjugated with alkaline phosphatase reacting with Fast Red chromogenic substrate. Slides were then counterstained with Mayer's 
TAB LE 2 Description of cumulative mortality data occurred during the challenge of lumpfish with the selected betanodaviruses

\begin{tabular}{|lllllll} 
Virus & $\begin{array}{l}\text { Number of } \\
\text { alive fish }\end{array}$ & No. of dead fish & Total & $\begin{array}{l}\text { \% Dead fish (reduced } \\
\text { survival) }\end{array}$ & Limlnf 95\% Cl & LimSup 95\% Cl \\
\hline 459.18/I12 & 64 & 15 & 79 & 18.99 & 10.34 & 27.64 \\
\hline AH95NorA & 62 & 15 & 77 & 19.48 & 10.63 & 28.33 \\
\hline SK-07 1324 & 68 & 11 & 79 & 13.92 & 21.56 & 15.19 \\
\hline Neg K & 22 & 10 & 32 & 31.25 & 47.31 \\
\hline
\end{tabular}

Note: Ninety fish per group (sixty in the control group) were infected, but fish sampled weekly for monitoring the infection were excluded from the calculation.

haematoxylin for 8 min and mounted in glycerol-gelatin. The presence of Betanodavirus antigens was characterized by bright red immunoprecipitates.

\subsection{Statistical analysis}

All statistical analyses were performed using the STATA 12.1 (StataCorp LLC) software. Each fish in the study was followed over time, and the event "death" was recorded. It included all diseased fish suppressed and excluded fish collected weekly for routine monitoring (censored). The Kaplan-Meier method was used to estimate the survival function from lifetime data (Van Belle, Fisher, Heagerty, \& Lumley, 2004). To compare the different survival curves, the nonparametric Wilcoxon-Breslow-Gehan test was used for equality of survivor functions. Chi-square test was used to compare cumulative mortality between independent groups. For two-paired comparison between the mortality in the control group and the mortality of each virus, two-sample test of proportions was used with an adjusted alpha (.017). The $95 \%$ confidence interval $(95 \% \mathrm{Cl})$ was calculated for each proportion through normal approximation. To compare the distributions of the quantitative variable $\mathrm{Ct}$ in rRT-PCR among survivors of the three independent groups (corresponding to the different viruses), the Kruskal-Wallis rank-sum test was used, after having evaluated the homogeneity of variances through non-parametric robust Levene test (W50: $p$-value $=.11$ ).

For two-paired comparison between viruses, two-sample Wilcoxon (Mann-Whitney) rank-sum test was used with an adjusted alpha (.017).

\section{3 | RESULTS}

\section{1 | Experimental infection}

A reduced survival of 36 infected lumpfish and 10 fish in the control group in the first two weeks was observed and was attributed to tail biting, a well-known behavioural problem in lumpfish. Among infected lumpfish, this anomalous behaviour occurred mostly in the Ah95NorA-infected group (15 fish) and the 459.18/I12-infected group (15 fish) followed by the SK-07 1324-infected group (11 fish). All these fish were collected and tested for NNV by rRT-PCR too (Table 2).
Statistical analysis applied to cumulative mortality (chi-square test) showed that there was no significant difference among viruses $(p$-value $=0.218)$

\section{2 | rRT-PCR results}

All brain samples from the control group tested negative by rRTPCR. Conversely, all samples from infected fish tested positive, regardless of the infection virus. $\mathrm{Ct}$ values were consistent over time in samples from the group infected with $459.18 / 112$ with a mean value of $26.48 \mathrm{Ct}$. In groups infected with SK-07 1324 and Ah95NorA, an increase in viral RNA copies was observed after days 14 and 21 post-challenge with mean Ct values of 17.29 and 15.35 , respectively.

Statistical analysis (Kruskal-Wallis test) applied on Ct values of survivors revealed that $\mathrm{Ct}$ values were significantly different ( $p$ value $=.0001$ ) between viruses. The $459.18 / 112$ virus showed the highest $\mathrm{Ct}$ values corresponding to the lowest amount of viral RNA. Two-paired comparisons confirmed that there is a significant difference between all three viruses (Wilcoxon test: $p$-value $=.0000$ ), with median value higher for 459.18/I12 (median $=26.2$ ) and lower for SK-07 1,324 $($ median $=12.1)($ Figure 1$)$.

\section{3 | Viral isolation results}

Due to the extensive positivity of brain samples on molecular diagnostic methods, selected samples were confirmed by virus isolation. All samples tested were positive by viral isolation, but with differing times of appearance of cytopathic effect (CPE). Notably, samples from fish suppressed due to tail biting at the early phase of infection had longer time for appearance of CPE, while samples obtained from survivors during the fourth week of infection generally showed CPE within a few days.

In order to quantify the viral amount at the end of the trial in survivors and to compare viral titration data with $\mathrm{Ct}$ values obtained in rRT-PCR, an additional 4 samples selected according to the $\mathrm{Ct}$ range were titrated in cell culture. Results of viral titration and $\mathrm{Ct}$ values showed full concordance, with the samples with highest Ct containing an average viral amount of $10^{3.36} \mathrm{TCID}_{50} / \mathrm{ml}$ and the samples with lowest $\mathrm{Ct}$ containing an average viral amount of $10^{9.17} \mathrm{TCID}_{50} /$ $\mathrm{ml}$ (Table 3). 


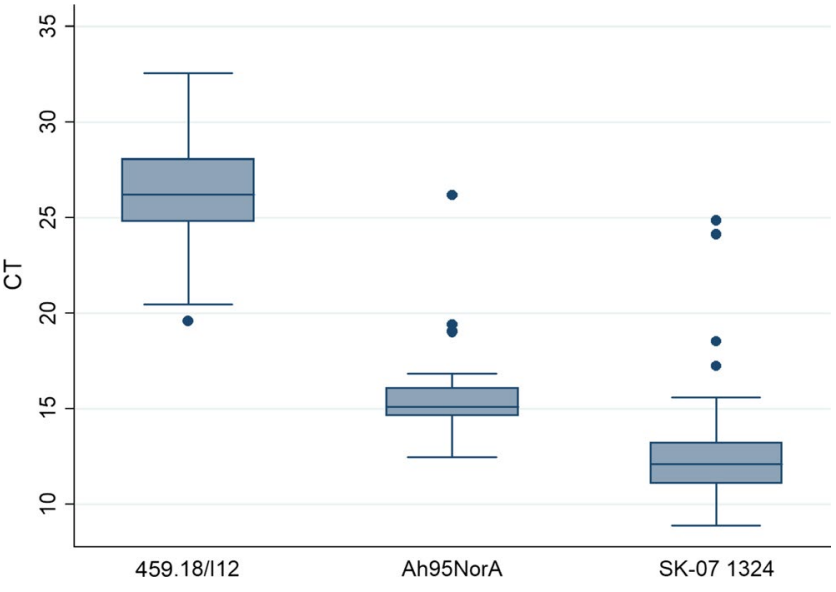

FIGURE 1 Box plot and whisker graph showing characteristic of the $\mathrm{Ct}$ values detected in survivors from different experimental groups. Median value is plotted inside the boxes, while dots correspond to outliers

\subsection{Histological results}

A few specimens of lumpfish processed at the beginning of the study were collected (two fish from the 459.18/I12 virus group and four fish from the SK-07 1324 virus group). These samples did not show any lesion referable to Betanodavirus infection and appeared negative in IHC analysis, but ulcerative lesions consistent with tail biting were present.

Samples collected at the end of the study from the survivors infected with 459.18/I12 virus showed no histological lesions (Figure 2a) and only mild immunoprecipitates in medulla oblongata (Figure 2b).

In the samples collected from survivors infected with Ah95NorA and SK-07 1324 viruses, histopathological analysis revealed the presence of multiple and extensive lesions on the CNS, characterized by diffuse intracytoplasmatic vacuolation and necrosis of nervous cells. The lesions were found in telencephalon, mesencephalon (stratum periventriculare of the optic tectum, tegmentum), diencephaIon (hypothalamus), metencephalon (cerebellum and valvula cerebelli) and medulla oblongata; the retina was also affected and vacuolations were recorded in the inner nuclear layer and in the ganglion cell layer. The presence of Betanodavirus antigens was characterized by bright red immunoprecipitates in the aforementioned tissues (Figure 2c-f), frequently associated with vacuolation. Moreover, immunoprecipitates highlighted the viral replication also in the inner

TABLE 3 Mean $(n=4)$ viral titres in brain samples from lumpfish collected at the end of the experiment ( $28 \mathrm{dpi}$ )

\begin{tabular}{lll} 
Categories of Ct & Mean Ct values & $\begin{array}{l}\text { Mean viral titre } \\
\left(\mathrm{TCID}_{50} / \mathrm{ml}\right)\end{array}$ \\
\hline$<30.00>25.00$ & 27.88 & $10^{3.36}$ \\
$<25.00>15.00$ & 17.72 & $10^{7.73}$ \\
$<15.00$ & 11.25 & $10^{9.17}$ \\
\hline
\end{tabular}

and outer plexiform layers and in the visual cell layer (mostly cones) of the retina (Figure 2e).

All samples from the control group were negative by IHC analysis.

\section{CONCLUSIONS AND DISCUSSION}

There is currently a considerable interest in learning more about the biology, health challenges and welfare of cleaner fish, including lumpfish (Speare, 2018). In view of the extensive use of cleaner fish in salmon parasite control, many scientists have started looking at the diseases affecting these species and in particular at the risk of transmission of diseases between cleaner fish and salmon. In recent years, some authors have undertaken studies to verify whether salmon diseases could be transferred to cleaner fish and whether, on the other hand, cleaner fish could be considered a risk for salmon. At the same time, the possible interspecies disease transmission between different cleaner fish species, that is lumpfish and wrasse species (Labridae spp.), remains poorly understood.

Our study is the first experimental infection with NNV in lumpfish, and due to the paucity of data available, a standard marine fish challenge method was implemented: IM infection with $0.1 \mathrm{ml}$ of $10^{5}$ $\mathrm{TCID}_{50} / \mathrm{ml}$ per fish, followed by 4 weeks of observation.

During the experiment, aggressive behaviour was observed inside the tanks causing a reduced survival in all groups which was attributed to tail biting. Aggression is a well-known behavioural problem in lumpfish (Imsland et al., 2016; Lein, Kolarevic, \& Espmark, 2017). This problem affected all groups, including the negative control group during the first two weeks of the challenge, and then gradually disappeared following modifications to husbandry. Affected fish did not present nervous signs, nor NNV-related lesions in the brain nor immunoprecipitates, and the RNA amount detected by rRT-PCR was attributable to the infection dose, supporting tail biting and not NNV-related pathology as being responsible for reduced survival. Therefore, it was concluded that the reduced survival was "misleading" data, not directly related to virus infection.

Randomly chosen, apparently healthy fish as well as survivors at the end of the study all tested positive for virus, and histopathological lesions typically associated with VNN in other species were observed. Among survivors, the amount of viral RNA was particularly high in the BFNNV-infected groups. In fact, while $\mathrm{Ct}$ values were homogeneous over time in samples from the group infected with 459.18/I12, values from groups infected with SK-07 1324 and Ah95NorA appeared to increase over time, supporting active viral replication in this host. This difference was further confirmed by statistical analysis.

Notably, the rRT-PCR performed in this study, despite being applied in a qualitative rather than quantitative approach, showed a perfect correlation with viral isolation and titration results. In fact, all samples tested turned out to be positive by virus isolation too, but with different viral titres. All samples collected from the RGNNV 459.18/I12 group required a second blind passage in cell culture in order to be properly cultivated. On the other 

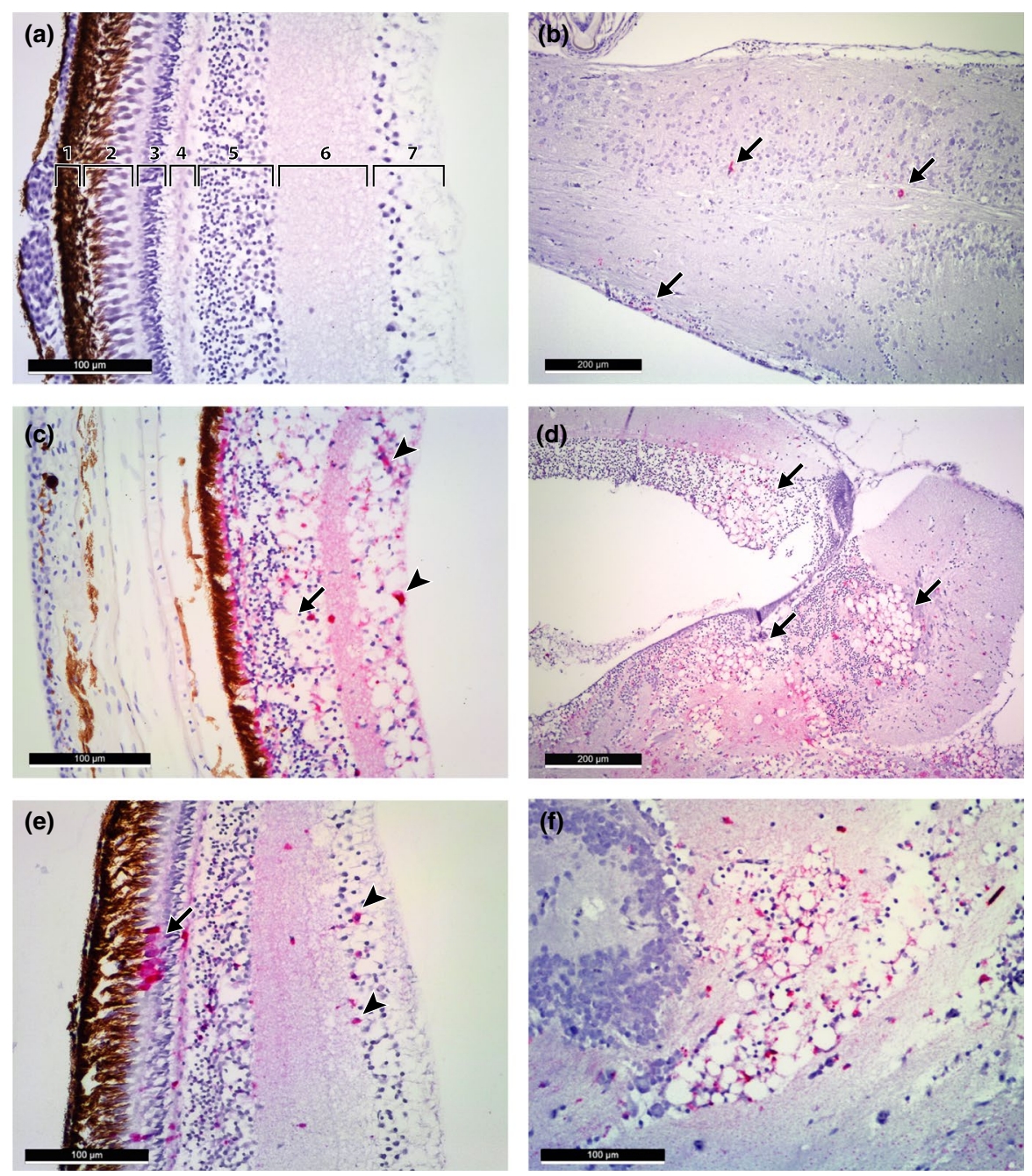

FIGURE 2 IHC analysis of the central nervous system of fish suppressed at the end of the study, characterized by multiple intracytoplasmatic vacuolations and necrosis of nervous cells. The presence of Betanodavirus antigens was revealed by bright red immunoprecipitates. (a) Normal retina from a survivor lumpfish infected with 459.18/I12 (25×). This picture shows labelled retinal layers following Ahmad, Paradis, Boyce, McDonald, and Gendron (2019): 1-retinal pigment epithelium; 2-visual cell layer; 3-outer nuclear layer; 4-outer plexiform layer; 5-inner nuclear layer; 6-inner plexiform layer; and 7-ganglion cell layer. (b) Mild IHC immunoprecipitates (arrows) in the medulla oblongata of 459.18/I12-infected specimen (10X). (c) Vacuoles and IHC precipitates in the ganglion cell layer (arrowheads), inner nuclear layer (arrow) and outer plexiform layer of the retina $(25 \times)$ and (d) in the mesencephalon (stratum periventriculare of the optic tectum, tegmentum) and metencephalon (cerebellum and valvula cerebelli) (10x) of AH95NorA-infected specimen (arrows). (e) Mild vacuolization in the ganglion cell layer of the retina (arrowheads) with immunoprecipitates in the inner and outer plexiform layers, inner nuclear layer and visual cell layer (cones) (arrow) (25x) of SK-07 1324-infected samples. (f) Vacuolations and immunoprecipitates in the diencephalon (hypothalamus) of SK-07 1324-infected specimen (25×)

hand, samples collected from groups infected with BFNNV were steadily isolated after a single passage in cell culture. Therefore, the earlier the week of infection, the longer the time for isolation was. Samples obtained from survivors of BFNNV-infected groups (week 4 post-infection) were generally isolated in a few days. These results demonstrated that the lumpfish is susceptible to Betanodavirus.

The different kinetics observed in terms of viral titre of the three viruses used in this study can be explained considering their different optimal replication temperatures: "warm-water" RGNNV has high-temperature tropism (Chi, Lin, Su, \& Hu, 1999; Hata et al., 2010) and should be isolated at 25 degrees and the water temperature $\left(12^{\circ} \mathrm{C}\right)$ maintained during the trial has hampered its capacity of replicating (OIE, 2017).

The results obtained by virological investigations both on cell culture and by rRT-PCR are further supported by histopathological assessment and immunohistochemistry assay. Remarkably, no histopathological lesions nor immunoprecipitates were observed in fish with pathology attributed to tail biting collected during the first two weeks of the trial. On the other hand, all samples collected from survivors at the end of the study $(28 \mathrm{dpc})$ were positive for the presence of specific NNV immunoprecipitates, associated with severe vacuolization of CNS and retina in both BFNNV-infected groups. Again in the RGNNV-infected group survivors, the lower viral replication 
was indicated by milder IHC precipitates compared to the BFNNVinfected groups.

The experiment was terminated 28 days post-challenge without observing clinical disease related to VNN; however, it is possible to speculate that BFNNV-challenged fish would have developed clinical signs due to extensive presence of severe pathological lesions in eyes and brain. Furthermore, the high prevalence of positive fish at the end of the trial with viable viral particles supports the establishment of carrier state. Future long-term studies are needed to determine whether NNV could cause clinical disease in lumpfish in different environmental conditions. Further studies will also be necessary to verify the susceptibility of the lumpfish to natural infection (by bath) and to characterize shedding phase. Considering the high infectious titre of virus in BFNNV-infected groups, the spreading of the disease from infected lumpfish is considered highly probable.

A study conducted in 2005 by Korsnes, Devold, Nerland, \& Nylund, 2005 showed that after administering a betanodavirus derived from the Atlantic halibut (Hippoglossus hippoglossus) to Atlantic salmon by intraperitoneal injection, the virus was able to replicate in Atlantic salmon and was transported to the medulla oblongata from the intraperitoneal injection site (Korsnes, et al, 2005). However, the same virus was not able to cause mortality and establish a persistent infection in the surviving challenged salmon. The risk of transmission of VNN from infected lumpfish to salmon therefore seems low.

A relevant risk to further assess is the possibility of intraspecies transmission of NNV or the transmission to other cleaner fish species (i.e. wrasse) possibly present in the same sea cage or area. Due to the Betanodavirus capacity to actively replicate in challenged lumpfish demonstrated by this study, it appears likely that they could act as virus amplifiers and possibly spread the disease.

During our study, lumpfish did not show clinical signs attributed to NNV infection, nor reduce survival (barring the exception of those fish suffering from behavioural problems, i.e. tail biting); however, no zootechnical parameters (i.e. feed intake, weight gain) were monitored during the challenge study. The infection could have reduced the feeding rate or impacted lumpfish's susceptibility to other infections. These aspects require examination to better understand the impact of NNV infection on lumpfish and implications to the use of this species.

Lastly, lumpfish, as many other cleaner fish, are currently moved between countries with very limited health monitoring requirements and only recently they have been listed among susceptible species for VHSV, a notifiable disease according to European legislation, enhancing surveillance and screening of these species. In future, broader surveillance for relevant pathogens prior to deployment into cage and sea transfer is recommended to limit the spread of pathogens and enhance the use of highly efficient cleaner fish.

\section{ACKNOWLEDGEMENT}

This project was funded by AQUAEXCEL2020 and ParaFishControl, two Horizon 2020 research infrastructure projects aiming to support the sustainable growth of the aquaculture sector in Europe.
Special thanks to Miriam Abbadi for genetic characterization of the viruses.

\section{DATA AVAILABILITY STATEMENT}

Generated sequences are published in GenBank.

\section{CONFLICT OF INTEREST}

The authors declare they have no competing interests.

\section{ORCID}

Anna Toffan (D) https://orcid.org/0000-0003-4389-3489

Niccolò Vendramin iD https://orcid.org/0000-0002-9217-7887

\section{REFERENCES}

Ahmad, R., Paradis, H., Boyce, D., McDonald, J., \& Gendron, R. L. (2019). Novel characteristics of the cultured Lumpfish Cyclopterus lumpus eye during post-hatch larval and juvenile developmental stages. Journal of Fish Biology, 94, 297-312. https://doi.org/10.1111/ jfb.13892

Alarcón, M., Gulla, S., Røsæg, M. V., Rønneseth, A., Wergeland, H., Poppe, T. T., ... Colquhoun, D. J. (2016). Pasteurellosis in lumpsucker Cyclopterus lumpus, farmed in Norway. Journal of Fish Diseases, 39, 489-495. https://doi.org/10.1111/jfd.12366

Alarcón, M., Thoen, E., Poppe, T. T., Bornø, G., Mohammad, S. N., \& Hansen, H. (2016). Co-infection of Nucleospora cyclopteri (Microsporidia) and Kudoa islandica (Myxozoa) in farmed lumpfish, Cyclopterus lumpus L., in Norway: A case report. Journal of Fish Diseases, 39, 411-418. https ://doi.org/10.1111/jfd.12372

Baud, M., Cabon, J., Salomoni, A., Toffan, A., Panzarin, V., \& Bigarré, L. (2015). First generic one step real-time Taqman RT-PCR targeting the RNA1 of betanodaviruses. Journal of Virological Methods, 211, 1-7. https://doi.org/10.1016/j.jviromet.2014.09.016

Bolton-Warberg, M. (2018). An overview of cleaner fish use in Ireland. Journal of Fish Diseases, 41, 935-939. https://doi.org/10.1111/ jfd.12731

Breuil, G., Bonami, J. R., Pepin, J. F., \& Pichot, Y. (1991). Viral infection (picorna-like virus) associated with mass mortalities in hatchery-reared sea-bass (Dicentrarchus labrax) larvae and juveniles. Aquaculture, 97, 109-116. https://doi.org/10.1016/0044-8486(91)90258-9

Chi, S. C., Lin, S. C., Su, H. M., \& Hu, W. W. (1999). Temperature effect on nervous necrosis virus infection in grouper cell line and in grouper larvae. Virus Research, 63, 107-114. https://doi.org/10.1016/ S0168-1702(99)00063-5

Chi, S. C., Lo, C. F., Kou, G. H., Chang, P. S., Peng, S. E., \& Chen, S. N. (1997). Mass mortalities associated with viral nervous necrosis (VNN) disease in two species of hatchery-reared grouper, Epinephelus fuscogutatus and Epinephelus akaara (Temminck and Schlegel). Journal of Fish Diseases, 20, 185-193. https://doi. org/10.1046/j.1365-2761.1997.00291.x

Doan, Q. K., Vandeputte, M., Chatain, B., Morin, T., \& Allal, F. (2017). Viral encephalopathy and retinopathy in aquaculture: A review. Journal of Fish Diseases, 40, 717-742. https://doi.org/10.1111/ jfd.12541

Fijan, N., Sulimanović, D., Bearzotti, M., Muzinić, D., Zwillenberg, L. O., Chilmonczyk, S., ... de Kinkelin, P. (1983). Some properties of the Epithelioma papulosum cyprini (EPC) cell line from carp Cyprinus 
carpio. Annales de l'Institut Pasteur. Virology, 134, 207-220. https:// doi.org/10.1016/S0769-2617(83)80060-4

Finney, D. J. (1978). Statistical method in biological assay. London: Charles Griffin \& Co. Ltd. 508 P.https://doi.org/10.2307/2982559

Frerichs, G. N., Tweedie, A., Starkey, W. G., \& Richards, R. H. (2000). Temperature, $\mathrm{pH}$ and electrolyte sensitivity, and heat, UV and disinfectant inactivation of sea bass (Dicentrarchus labrax) neuropathy nodavirus. Aquaculture, 185, 13-24. https://doi.org/10.1016/ S0044-8486(99)00337-3

Grotmol, S., Nerland, A. H., Biering, E., Totland, G. K., \& Nishizawa, T. (2000). Characterisation of the capsid protein gene from a nodavirus strain affecting the Atlantic halibut Hippoglossus hippoglossus and design of an optimal reverse-transcriptase polymerase chain reaction (RT-PCR) detection assay. Diseases of Aquatic Organisms, 39, 79-88. https://doi.org/10.3354/dao039079

Grotmol, S., Totland, G. K., Thorud, K., \& Hjeltnes, B. K. (1997). Vacuolating encephalopathy and retinopathy associated with a nodavirus-like agent: A probable cause of mass mortality of cultured larval and juvenile Atlantic halibut Hippoglossus hippoglossus. Disease of Aquatic Organisms, 29, 85-97. https://doi.org/10.3354/dao029085

Grove, S., Johansen, R., Dannevig, B. H., Reitan, L. J., \& Ranheim, T. (2003). Experimental infection of Atlantic halibut Hippoglossus hippoglossus with nodavirus: Tissue distribution and immune response. Diseases of Aquatic Organisms, 53, 211-221. https://doi.org/10.3354/ dao053211

Guðmundsdóttir, S., Vendramin, N., Cuenca, A., Sigurðardóttir, H., Kristmundsson, A., Iburg, T. M., \& Olesen, N. J. (2019). Outbreak of viral haemorrhagic septicaemia (VHS) in lumpfish (Cyclopterus lumpus) in Iceland caused by VHS virus genotype IV. Journal of Fish Diseases, 42, 47-62. https://doi.org/10.1111/jfd.12910

Hata, N., Okinaka, Y., Iwamoto, T., Kawato, Y., Mori, K. I., \& Nakai, T. (2010). Identification of RNA regions that determine temperature sensitivities in betanodaviruses. Archives of Virology, 155, 15971606. https://doi.org/10.1007/s00705-010-0736-7

Hjeltnes, B. (2014). Farmed fish Health Report 2013. Norwegian Veterinary Institute, Oslo. http://www.Vetinst.No/Eng/Publicatio ns/Fish-Health-Report

Imsland, A. K., Reynolds, P., Eliassen, G., Hangstad, T. A., Foss, A., Vikingstad, E., \& Elvegård, T. A. (2014). The use of lumpfish (Cyclopterus lumpus L.) to control sea lice (Lepeophtheirus salmonis Krøyer) infestations in intensively farmed Atlantic salmon (Salmo salar L.). Aquaculture, 424-425, 18-23. https://doi.org/10.1016/j. aquaculture.2013.12.033

Imsland, A. K., Reynolds, P., Eliassen, G., Hangstad, T. A., Jónsdóttir, Ó. D. B., Elvegård, T. A., ... Nytrø, A. V. (2016). Investigation of behavioural interactions between lumpfish (Cyclopterus lumpus) and goldsinny wrasse (Ctenolabrus rupestris) under controlled conditions. Aquaculture International, 24, 1509-1521. https://doi.org/10.1007/ s10499-016-0008-y

Johansen, R. (2013). Farmed fish health report 2012, Norwegian Veterinary Institute, Oslo. http://www.vetinst.no/eng/Publications/Fish-Health

Jonassen, T., Remen, M., Lekva, A., Steinarsson, A., Árnason, T. (2018). Transport of lumpfish and wrasse. In J. W. Treasurer (Ed.), Cleaner fish biology and aquaculture applications (319-335) Sheffield: 5M Publishing Ltd.

Korsnes, K., Devold, M., Nerland, A. H., \& Nylund, A. (2005). Viral encephalopathy and retinopathy (VER) in Atlantic salmon, Salmo salar, after intraperitoneal challenge with a nodavirus from Atlantic halibut, Hippoglossus hippoglossus. Diseases of Aquatic Organisms, 68, 7-15. https://doi.org/10.3354/dao068007

Korsnes, K., Karlsbakk, E., Skår, C. K., Sælemyr, L., Nylund, A., Kvamme, B. O., \& Mortensen, S. (2017). High nervous necrosis virus (NNV) diversity in wild wrasse (Labridae) in Norway and Sweden. Diseases of Aquatic Organisms, 126, 43-50. https://doi.org/10.3354/dao03159
Lein, I., Kolarevic, J., Espmark, Å. M. E. (2017). Performance and welfare of lumpfish Cyclopterus lumpus juveniles reared at different densities. Proceeding of Aquaculture Europe 2017, 17-20 October 2017, Dubrovnik, Croatia. https://www.was.org/easonline/AbstractDetail. aspx?i=8665

Lopez-Jimena, B., Alonso, M. D. C., Thompson, K. D., Adams, A., Infante, C., Castro, D., ... Garcia-Rosado, E. (2011). Tissue distribution of red spotted grouper nervous necrosis virus (RGNNV) genome in experimentally infected juvenile European seabass (Dicentrarchus labrax). Veterinary Microbiology, 154, 86-95. https://doi.org/10.1016/j. vetmic.2011.06.029

Maltese, C., \& Bovo, G. (2007). Monografie. Viral encephalopathy and retinopathy. Ittiopatologia, 4, 93-146.

Marcos-López, M., Donald, K., Stagg, H., \& McCarthy, U. (2013). Clinical Vibrio anguillarum infection in lumpsucker Cyclopterus lumpus in Scotland. The Veterinary Record, 173, 319. https://doi.org/10.1136/ vr.101763

Mladineo, I. (2003). The immunohistochemical study of nodavirus changes in larval, juvenile and adult sea bass tissue. Journal of Applied Ichthyology, 19, 366-370. https://doi. org/10.1111/j.1439-0426.2003.00489.x

Munday, B. L., Kwang, J., \& Moody, N. (2002). Betanodavirus infections of teleost fish: A review. Journal of Fish Diseases, 25, 127-142. https:// doi.org/10.1046/j.1365-2761.2002.00350.x

Mutinelli, F., Bozza, M. A., Basilicata, L., \& Bovo, G. (1998) Diagnosi istologica ed immunoistochimica della encefaloretinopatia virale della spigola di allevamento (Dicentrarchus labrax). Bollettino Società Italiana Patologia Ittica, 23, 1-10.

OIE (World Organization for Animal Health) (2017). Manual of diagnostic tests for aquatic animals 2017. Viral encephalopathy and retinopathy, Chapter 2.3.12.

Panzarin, V., Toffan, A., Abbadi, M., Buratin, A., Mancin, M., Braaen, S., ... Cattoli, G. (2016). Molecular basis for antigenic diversity of genus Betanodavirus. PLoS ONE, 11(7), e0158814. https://doi.org/10.1371/ journal.pone.0158814

Patel, S., Korsnes, K., Bergh, Ø., Vik-Mo, F., Pedersen, J., \& Nerland, A. H. (2007). Nodavirus in farmed Atlantic cod Gadus morhua in Norway. Diseases of Aquatic Organisms, 77, 169-173. https://doi.org/10.3354/ dao01842

Poppe, T. T., Taksdal, T., Skjelstad, H., Sviland, C., Vågnes, Ø., \& Colquhoun, D. J. (2012). Nye arter- nye diagnostiske utfordringer (New species New diagnostic challenges). Norsk Veterinær Tidsskrift, 124, 19-21. (In Norwegian).

Powell, A., Treasurer, J. W., Pooley, C. L., Keay, A. J., Lloyd, R., Imsland, A. K., \& Garcia de Leaniz, C. (2018). Use of lumpfish for sea-lice control in salmon farming: Challenges and opportunities. Reviews in Aquaculture, 10, 683-702. https://doi.org/10.1111/raq.12194

Rigos, G., \& Katharios, P. (2010). Pathological obstacles of newly-introduced fish species in Mediterranean mariculture: A review. Reviews in Fish Biology and Fisheries, 20, 47-70. https://doi.org/10.1007/ s11160-009-9120-7

Rimstad, E., Basic, D., Gulla, S., Hjeltnes, B., \& Mortensen, S. (2017). Risk assessment of fish health associated with the use of cleaner fish in aquaculture. Opinion of the Panel on Animal Health and Welfare of the Norwegian Scientific Committee for Food and Environment, 32, 68. https://www.vkm.no/english/riskassessments/allpublications/clean erfishandtherisksoftransmittinginfectiontofarmedsalmon.4.40cd6 1cf160507e9844aa66.html

Scholz, F., Fringuelli, E., Bolton-Warberg, M., Marcos-López, M., Mitchell, S., Prodhol, P., ... Rodger, H. D. (2017). First record of Tetramicra brevifilum in lumpfish (Cyclopterus lumpus, L.). Journal of Fish Diseases, 40, 757-771. https://doi.org/10.1111/jfd.12554

Scholz, F., Ruane, N. M., Marcos-Lopez, M., Mitchell, S., Bolton-Warberg, M., O'Connor, I., ... Rodger, H. D. (2018). Systemic mycoses in lumpfish 
(Cyclopterus lumpus L.) in Ireland: Aetiology and clinical presentation. Bulletin of the European Association of Fish Pathologists, 38, 202-212.

Scholz, F., Ruane, N. M., Morrissey, T., Marcos-López, M., Mitchell, S., O'Connor, I., ... Rodger, H. D. (2018). Piscine myocarditis virus detected in corkwing wrasse (Symphodus melops) and ballan wrasse (Labrus bergylta). Journal of Fish Diseases, 41, 147-152. https://doi. org/10.1111/jfd.12661

Shetty, M., Maiti, B., Santhosh, K. S., Venugopal, M. N., \& Karunasagar, I. (2012). Betanodavirus of marine and freshwater fish: Distribution, genomic organization, diagnosis and control measures. Indian Journal of Virology, 23, 114-212. https://doi.org/10.1007/s13337-012-0088-x

Skoge, R. H., Brattespe, J., Økland, A. L., Plarre, H., \& Nylund, A. (2018). New virus of the family Flaviviridae detected in lumpfish (Cyclopterus lumpus). Archives of Virology, 163, 679-685. https://doi.org/10.1007/ s00705-017-3643-3

Speare, D. J. (2018). Cleaner fish diseases. Journal of Fish Diseases, 42, 155-156. https://doi.org/10.1111/jfd.12937

Stagg, H., Guðmundsdóttir, S., Vendramin, N., Ruane, N., Sigurðardóttir, H., Christiansen, H. D., ... Jorgen Olesen, N. (2017) Isolation and characterisation of a new ranavirus isolated from lumpfish in the north Atlantic area. Proceeding of the 4th International Symposium on Ranaviruses 7-10 June 2017, Budapest, Hungary. https://www. ranavirus.org/wp-content/uploads/2017/02/ISR2017_Budapest_ AbstractBook.pdf

Toffan, A., \& Patarnello, P. (2013). Viral encephalopathy and retinopathy: The first viral threat for Mediterranean fish. Report on the 17th Annual Meeting of the National Reference Laboratories for Fish Diseases Copenhagen, Denmark, May 29-30, 2013, P35.

Totland, G. K., Grotmol, S., Morita, Y., Nishioka, T., \& Nakai, T. (1999). Pathogenicity of nodavirus strains from striped jack Pseudocaranx dentex and Atlantic halibut Hippoglossus hippoglossus, studied by waterborne challenge of yolk-sac larvae of both teleost species. Diseases of Aquatic Organisms, 38, pp. 169-175. http://www.ncbi. nlm.nih. https://doi.org/10.3354/dao038169

Treasurer, J. W. (2002). A review of potential pathogens of sea lice and the application of cleaner fish in biological control. Pest Management Science, 58, 546-558. https://doi.org/10.1002/ps.509
Treasurer, J. W., \& Birkbeck, T. H. (2018). Pseudomonas anguilliseptica associated with mortalities in lumpfish (Cyclopterus lumpus L.) reared in Scotland. Bulletin of the European Association of Fish Pathologists, 38, 222-224.

Van Belle, G., Fisher, L. D., Heagerty, P. J., \& Lumley, T. S. (2004). Biostatistics: A methodology for the health sciences. Journal of the Royal Statistical Society. Series A (Statistics in Society), 157(2), 306. https://doi.org/10.2307/2983369

Vendramin, N., Toffan, A., Mancin, M., Cappellozza, E., Panzarin, V., Bovo, G., ... Terregino, C. (2014). Comparative pathogenicity study of ten different betanodavirus strains in experimentally infected European sea bass, Dicentrarchus labrax (L.). Journal of Fish Diseases, 37, 371-383. https://doi.org/10.1111/jfd.12117

Walker, P. J., \& Winton, J. R. (2010). Emerging viral diseases of fish and shrimp. Veterinary Research, 41(6), 51. https://doi.org/10.1051/vetre $\mathrm{s} / 2010022$

Wolf, K., \& Quimby, M. C. (1962). Established eurythermic line of fish cells in vitro. Science, 135, 3508. https://doi.org/10.1126/scien ce.135.3508.1065

Yoshikoshi, K., \& Inoue, K. (1990). Viral nervous necrosis in hatcheryreared larvae and juveniles of Japanese parrotfish, Oplegnathus fasciatus (Temminck \& Schlegel). Journal of Fish Diseases, 13, 67-77. https://doi.org/10.1111/j.1365-2761.1990.tb00758.x

How to cite this article: Toffan A, De Salvador M, Scholz F, et al. Lumpfish (Cyclopterus lumpus, Linnaeus) is susceptible to viral nervous necrosis: Result of an experimental infection with different genotypes of Betanodavirus. J Fish Dis. 2019;00:1-10. https://doi.org/10.1111/jfd.13088 